\title{
Exploring Pedagogical Difficulties in Teaching Mother Tongue: Underpinnings of Intervention Program
}

\author{
Leonora F. De Jesus \\ Bulacan State University
}

\begin{abstract}
Mother Tongue Based-Multilingual Education (MTB-MLE) program promotes the development of individuals and shall be implemented as a subject area and as medium of instruction in the primary level under the K to 12 Curriculum in the Philippines. Teachers of the first graders are the frontlines displaying levels of determination in teaching Mother Tongue (MT). Various teaching strategies are teachers' leeway to make the lesson easy to understand. This paper described the strategies of teachers in teaching MT; their difficulties and live experiences even the proposed intervention were presented. Included in the process is the careful analysis of narratives' codes; the text was subjected to phenomenological reduction. The multiple themes that emerged from the interview were analysed thematically. Study revealed that demonstration, game-based learning and differentiated instruction are frequently used strategies of teachers; these are the most motivating and stimulating to learners as perceived by them. Furthermore, teachers' difficulty is not directly connected to strategy; rather, to the lack of Mother Tongue visuals and multimedia materials and equipment.
\end{abstract}

Keywords: pedagogical difficulties, mother tongue, intervention program, multilingual education, teaching strategies

\section{INTRODUCTION}

Basic Education Curriculum of 2002 in the Philippines was changed to Enhanced Basic Education Curriculum in 2013. One of the many changes brought by the new curriculum was the implementation of Mother Tongue-Based Multilingual Education (MTB-MLE). It is the "first-language-first" education which begins in the mother tongue and transitions to additional languages, particularly Filipino and English. MTBMLE aims to promote the development of competent and well- rounded individuals. Learners begin their education in the language they understand best and develop a strong foundation. When learners easily understand their mother tongue language then it is easier for them to deal with other subjects; learners can immediately construct and articulate their thoughts. In the implementing guidelines set by the Department of Education, the MTB-MLE shall be implemented in two modes: as a learning/ subject area and as a medium of instruction. Mother Tongue shall be used as a medium of instruction in all learning areas from Kindergarten through Grade 3 except Filipino and English subjects. Mother Tongue (MT) as a subject will focus on the development of beginning reading and fluency from Grades 1 to 3 . It is expected that by the end of grade III, students will enjoy communicating in their first language (L1) on familiar topics for a variety of purposes and audiences using basic vocabulary, and phrases; read L1 texts with understanding, and create their own stories and texts in their L1. (K to 12 Curriculum Guide MTBMLE Curriculum 
Framework, 2016). As stated in the Department Order No. 16, series 2012, there are twelve major languages or Lingua Franca which shall be utilized as language of instruction for Kindergarten to Grade 3 pupils who speak the same local languages, namely Tagalog,Hiligaynon, Kapampangan,Waray, Pangasinense,Tausug, Iloko, Maguindanaoan, Bikol, Cebuano, Maranao, and Chabacano (DepEd Order 16, 2012). Bulacan is part of Region III that uses Tagalog as its local language.

Moreover, the success of the MTB-MLE Program truly depends on the ingenuity and innovativeness of teachers in their pedagogy as well as their commitment to the program. Pedagogy refers to the "interactions between teachers, students, and the learning environment and the learning tasks" (Policy Toolbox, 2019). This broad term includes how teachers and students relate together as well as the instructional approaches implemented in the classroom. Teachers should display high levels of creativity in making their own instructional materials, know different teaching strategies, be resourceful and continuously adjust to the changing needs of the pupils (Teaching in mother tongues, 2018). Furthermore, teachers of the first graders are the frontlines displaying levels of creativity, resourcefulness and determination in teaching and even developing a working orthography of local languages in order to meet the student's individual needs and to achieve the goal of the Mother Tongue Based Multilingual Program. Recently, because of the changing society, the issue of teaching strategies and their effectiveness is the leading concern of the education sector. It is the responsibility of the teachers to ensure adequate teaching and learning as necessary to meet the changing needs of the industry. Students react differently to different teaching strategies, and that the selection of the proper strategy is critical to the learning style of those being served by the instruction. Students' individuality matters in teacher's selection of strategy; students learn with different styles, at different speeds, different levels of prior knowledge and different environments when the subject matter is given. There are two parameters in teaching methodology that teachers should look upon; these are teacher-centered approach and learner- centered approach. In a teacher -centered approach, the teacher cast herself in the role of being a master, an expert, a personal model and the main authority in the classroom. Learners on the other hand are presumed to be passive and copious recipients of knowledge from the teacher. Teacher-centered methods include demonstration, flipped classroom, direct instruction, and kinesthetic learning. In the learner-centered method, the teacher is both a teacher and a learner at the same time. The teacher also learns new things which she did not know in the process of teaching. She serves as a facilitator and a delegator of learning to her students. Teaching strategies that are learner-centered are personalized learning, game-based learning, inquiry-based learning, expeditionary learning and differentiated instruction (Teaching Methods, 2020).

In the study of Thomson (2012), she recommends strategies to be incorporated into practice by teachers to further improve the language support given to learners; these are thinking time, elaborated input, re-casts, questioning and verbal interaction. These strategies serve as scaffolding and draw the prior knowledge of the students. These will also allow them to connect, paraphrase, participate and ensure students exposure to authenticity of the language. On the other hand, various teaching strategies are used in sharing information; a leeway for a teacher in the teaching profession. Hence, this paper will describe the teaching strategies of teachers in teaching Mother Tongue subject; their difficulties and the possible program to enhance teachers' capability in teaching of Mother Tongue subject.

\section{STATEMENT OF THE PROBLEM}

1. What is the profile of the Mother Tongue teachers in the selected government schools in terms of:

a. gender;

b. academic qualification;

c. number of years in teaching Mother Tongue;

d. training in teaching strategies?

2. What are the teacher' strategies in teaching Mother Tongue subject?

3. How may the difficulties of teachers in teaching Mother Tongue be described?

4. What intervention program that will intensify the competency of teachers in teaching Mother Tongue Subject may be proposed? 


\section{METHODOLOGY}

This study used a Descriptive- mixed method with the use of mean, standard deviation, frequency and relative frequency distribution. Checklists and questionnaires were used to document the strategies and teachers' difficulties in teaching Mother Tongue. Lived experiences were presented in textual format. The paradigm adapts the input-process-output scheme. Input is steered by the related literature and studies and Department of Education circulars on the implementation of MTB-MLE. Process involves the listing and gathering of profiles, strategies and difficulties. This was followed by a careful analysis of narratives' codes to identify the trends and common themes of responses; the text was subjected to phenomenological reduction wherein some direct experiences were included in the presentation. The multiple themes that emerged from the interview were analyzed using thematic analysis; after which, the researcher posits that the expected output is the proposed intervention program to deepen the competency of teachers in teaching the Mother Tongue subject. Fifty Mother Tongue teachers from Grades 1 to 3 from different public elementary schools in Bulacan were the participants of this study. Thirty of them participated willfully in the parallel interview to share their experiences including difficulties and challenges in teaching Mother Tongue. Thirty participants adhered to the recommendation of the Archives of Sexual Behavior that 2530 participants is the minimum sample size required to reach saturation and redundancy if in-depth interview is to be done. This number is considered adequate because it may distinguish conceptual categories of interest, maximizes the possibility that enough data have been collected to clarify relationships between conceptual categories and identify variation in processes (Dworkin, 2012).

Table 1 below shows the number of participants and the school where teachers teach.

TABLE 1

\section{PARTICIPANTS OF THE STUDY}

\begin{tabular}{|l|c|}
\hline Elementary Schools in Bulacan and their Address & Number of Teacher Participants \\
\hline Borol 1 ${ }^{\text {st }}$ Elementary School- Balagtas, Bulacan & 2 \\
\hline Longos Elementary School - Balagtas, Bulacan & 3 \\
\hline Pungo Elementary School- Calumpit, Bulacan & 3 \\
\hline Mamerto Bernardo Memorial Central School- Pandi, Bulacan & 3 \\
\hline Balagtas Central School - Balagtas, Bulacan & 3 \\
\hline Abangan Sur Elementary School - Marilao, Bulacan & 3 \\
\hline Cay Pombo Elementary School - Sta. Maria, Bulacan & 3 \\
\hline Guyong Elementary School - Sta. Maria, Bulacan & 3 \\
\hline Dampol Elementary School - Plaridel, Bulacan & 3 \\
\hline Plaridel Elementary School - Plaridel, Bulacan & 3 \\
\hline Pulilan Central School - Pulilan, Bulacan & 3 \\
\hline Sta. Elena Elementary School - Hagonoy, Bulacan & 3 \\
\hline San Nicolas Elementary School - Hagonoy, Bulacan & 3 \\
\hline Paombong Elementary School - Paombong, Bulacan & 3 \\
\hline Longos Elementary School - Malolos, Bulacan & 3 \\
\hline Sta. Isabel Elementary School - Malolos, Bulacan & 3 \\
\hline San Agustin Elementary School - Malolos, Bulacan & 3 \\
\hline TOTAL & 50 \\
\hline
\end{tabular}

A local instrument based on the related literature and studies was made and used as a data gathering tool. This was evaluated and validated by a Research and Assessment Professor, Elementary Head Teacher and Language Professor. Comments and recommendations were considered in the revision of the 
instrument. Five-point Likert Scale was utilized to describe the use of teaching strategies in teaching Mother Tongue.

TABLE 2

RANGE AND DESCRIPTION OF SCALE

\begin{tabular}{|l|l|l|}
\hline Scale & Range & Description \\
\hline 5 & $4.50-5.0$ & Heavily and mostly used \\
4 & $3.50-4.49$ & Frequently used \\
3 & $2.50-3.49$ & Sometimes \\
2 & $1.50-2.49$ & Rarely used \\
1 & $1.0-1.49$ & Not used \\
\hline
\end{tabular}

\section{LIMITATIONS}

This study is limited only in pointing out the heavily and mostly used strategies in teaching Mother Tongue subject either teacher centered, or student centered; Mother Tongue as a medium of instruction in teaching different primary level subjects and comparing the learner -centered to teacher-centered strategies of teaching are the limitations of the study. All teacher participants are from the same province that uses Tagalog as their mother tongue (MT) or local language. Pupils from this location also use Tagalog and no other local languages are being utilized; but both are well-founded in Filipino as lingua-franca since they are using it at home and school with their parents, friends and peers. Hence, multiple languages and dialects will not be covered in the discussion except for code switching (CS) purposes of participants.

\section{RESULT AND DISCUSSION}

Demographic Profile of the Teachers

TABLE 3

\section{PROFILE OF THE MOTHER TONGUE TEACHERS}

\begin{tabular}{|l|l|l|}
\hline PROFILE & Frequency & $\begin{array}{l}\text { Rel. Freq. } \\
\text { (fN) }\end{array}$ \\
\hline $\begin{array}{l}\text { Gender } \\
\text { Male }\end{array}$ & 0 & 0 \\
Female & 50 & 1 \\
\hline Academic Qualification & & \\
Bachelor Degree & 13 & 0.26 \\
Bachelor Degree with M.A. units & 32 & 0.64 \\
Master's Degree holder & 5 & 0.1 \\
Master's Degree with PhD units & 0 & 0 \\
\hline Number of Years in Teaching Mother Tongue & & \\
$1-3$ & 12 & 0.24 \\
$4-7$ & 38 & 0.76 \\
\hline Trainings & & \\
None & 6 & 0.12 \\
$1-2$ & 25 & 0.5 \\
$3-4$ & 11 & 0.22 \\
$5-7$ & 8 & 0.16 \\
\hline
\end{tabular}


The table shows that teachers handling Mother Tongue subject are all female and academically qualified because all of them were bachelors' degree holders; most of them are currently taking their master's degree. According to Podolsky et al., (2019), teaching experience is positively associated with students' achievement. More experienced teachers confer benefits to their colleagues, their students and to the school as a whole. As teachers gain experience, students not only learn more, they are also more likely to do better on other measures of success. Teachers' effectiveness increases at a greater rate when they teach in a supportive working environment, and when they accumulate experience in the same grade level, subject, or district. As shown in the table, seventy six percent have more than three years of experience in teaching a Mother Tongue subject while the remaining has a year and/ or two years' experience that possibly means they are aware and knowledgeable enough to know the useful strategies they can use in teaching.

As mentioned in The Importance of Seminars and Trainings in Improving Teachers Performance (Teachers' Essay, 2013), training and seminars help create an effective learning environment, improve teaching- learning situations, keep updated on modern instructional devices and inspire them to become better teachers in the modern world. Boudersa (2016) also suggests in his study that teachers should receive adequate educational and professional training to equip them with new information and teaching skills. Table 3 shows that fifty percent of the teachers had attended training once or twice and more than 22 percent of them attended training thrice and more. The result shows that the Department of Education (DepEd) stood firm on its commitment in providing teachers and personnel with the needed training and development programs for their personal and professional growth; whom the teacher- respondents availed.

\section{Teaching Strategies in Teaching Mother Tongue}

TABLE 4

TEACHING STRATEGIES IN TEACHING MOTHER TONGUE

\begin{tabular}{|l|c|c|}
\hline \multicolumn{1}{|c|}{ TEACHING STRATEGIES } & MEAN & INTERPRETATION \\
\hline \multicolumn{1}{|c|}{ TEACHER-CENTERED } & 3.43 & Sometimes \\
\hline 1. Flipped classroom & 3.14 & Sometimes \\
\hline 2. Direct instruction & 3.82 & Frequently used \\
\hline 3. Kinesthetic learning & 3.5 & Frequently used \\
\hline 4. Demonstration strategy & 4.02 & Frequently used \\
\hline 5. Seminar type & 3.22 & Sometimes \\
\hline 6. Lecture using chalk and board & 3.66 & Frequently used \\
\hline 7. Resource people & 2.98 & Sometimes \\
\hline 8. Exhibit & 2.94 & Sometimes \\
\hline 9. Explicit (guided) instruction & 3.60 & Frequently used \\
\hline STUDENT- CENTERED & 3.41 & Sometimes \\
\hline 1. Game-based learning & 4 & Frequently used \\
\hline 2. Differentiated instruction & 4.02 & Frequently used \\
\hline 3. Personalized learning & 3.22 & Sometimes \\
\hline 4. Inquiry-based learning & 3.48 & Sometimes \\
\hline 5. Project-based learning (PBL) & 2.84 & Sometimes \\
\hline 6. Buzz groups & 2.96 & Sometimes \\
\hline 7. Role play & 3.6 & Frequently used \\
\hline 8. Study-assignment (self- study) & 3.2 & Sometimes \\
\hline 9. Individualized instruction & 3.42 & Sometimes \\
\hline 10. Simulation & 3.5 & Sometimes \\
\hline 11. Problem solving & 3.36 & Sometimes \\
\hline Grand Mean & $\mathbf{3 . 4 2}$ & Sometimes \\
\hline
\end{tabular}


Table 4 shows that teachers sometimes use the teacher and student- centered methods of teaching as seen in the computed average mean of 3.43 and 3.41. Among the teacher centered strategies, demonstration strategy got a mean of 4.02 while in the student- centered strategies game-based learning and differentiated instruction received the mean of 4.0 and 4.02 which all interpreted as frequently used strategies of teachers. Participants explained that they do demonstrations most of the time because their students are very young. They need to feel that they are just playing so that students are not bored; instead they are having fun while learning. Demonstration is a strategy of teaching how to or do something in a step-by-step process. Teachers somehow prefer to have demonstrations to effectively transmit information and improve learner's cognition. According to Basheer (2016), demonstration significantly improves students' understanding. If planned properly, demonstration can serve as an effective platform for enhancing students' understanding of concepts as well as increase their motivation and interest in learning Chemistry. This may be the same as the Mother Tongue subject if planned and used accordingly. According to Tomlinson (2003), Differentiated Instruction is an approach that enables teachers to plan strategically to meet the needs of every student. This concept is rooted in the belief that there is variability in the learners and the teachers and must accept the diversity and adjust their instruction accordingly. From the interview, teachers recapitulated that pupils were active in doing their task especially when they were grouped according to their ability but teachers admitted they initiated the differentiated instruction in their classes without getting the multiple intelligence result of each individual. Differentiated instruction addresses the unique learning styles and intelligences of students. Gardner's multiple intelligences will serve as a guiding lens to students with varied learning profiles; hence the conduct of differentiated instruction will be successful if multiple intelligence result was taken care of (Staum and Lax, 2019).On the other hand, Game- based learning relates to the use of games to enhance the learning experience of the children. A study has reported that educational games could enhance student's learning interest and motivation (Burguillo, 2010). Game -based learning is a system which is being increasingly applied in the educational process and which has been clearly evidenced in a number of scientific papers that have been published over the past decade (Vusic and Gecek, 2018). Teachers prefer games not only in motivating students but also in the presentation and discussion of their lesson because students are actively participating if they will play a game. Participants reasoned out that those strategies are the most useful for their lessons in Mother Tongue. They are appropriate to use and enhance students' learning. Also using those strategies make the students more interested in the lesson; the classes are lively and interactive.

On the other hand, though the mean of 2.98 (resource people) and 2.84 (project based) interpreted as sometimes using teaching strategies they are still the lowest among the means. Inviting resource persons to discuss Mother Tongue lessons is not easy to put forth. Teachers need to submit a proposal to their superior and prepare a lot of documents and wait for its approval to be allowed to conduct this strategy in their classroom; so they hardly do it. On the other hand, it is known that project-based learning (PBL) is a valuable classroom tool that reinforces a lesson or gives students an opportunity to demonstrate what they have learned. In the study of Guven et al (2014) they discovered that the grade 4 students greatly enjoyed the execution and presentation of the science and technology project given to them. On the latter, recommended that PBL can be made mandatory in schools. The participants of the current paper also agreed to some extent that PBL is beneficial to students but not to all the primary pupils. Hence, it should not be made mandatory to schools. Primary pupils belong to the pre-operational stage and the first quarter of the concrete operational stage of the cognitive development theory of Jean Piaget. There are criticisms that were mentioned on what children could not yet do on the pre-operational stage. The concepts of egocentrism and conservation are both centered on abilities that children have not yet developed; they see things differently (Susman, 2021). Pupils on this stage should be closely monitored if given group project; teachers' objective might fail if pupils are not guided properly. Some participants of this study reiterated that it's not easy to go around the classroom, offering constructive advice as pupils lead their own investigations even it is game -based; in which some teacher participants presumed project-based is inappropriate to children in the primary level unless the project will be done at home with the parents' supervision. 
Along with the declaration of the teachers on their teaching strategies, they profess that the choice of language to be used as medium of instruction for primary graders has to be considered. There was a time teachers were confused if they were using Tagalog or Filipino. Only to find out they do code switching (CS) instead; with the inclusion of English sometimes. This action found to be coherent to Perfecto's (2018) study when she stated that teachers practiced CS, translation, or metalinguistic comparison and contrast and explanation, they used at least three languages namely MT, Filipino, and English in order to facilitate the students' learning. In the current study, teachers admit that they use language/s they are good at and when they feel comfortable using it; whether it is their MT, Filipino or English. This impression was not surprising because there were teachers who were comfortable in speaking the school mother tongue than the individual mother tongues (Kirby, 2020).

TABLE 5

MEAN, STANDARD DEVIATION AND STANDARD ERROR OF TEACHING STRATEGIES

\begin{tabular}{|l|l|l|l|}
\hline Teaching Strategies & Mean & SD & SE \\
\hline $\begin{array}{l}\text { Combination of teacher and student centered } \\
\text { teaching strategies }\end{array}$ & 3.42 & 0.3654 & 0.0817 \\
\hline
\end{tabular}

Low standard deviation (SD) means data are clustered around the mean, and high standard deviation indicates data are more spread out (Standard Deviation, 2012). The table shows that the SD of 0.3654 is considered a low SD which means that the mean values are close to one another. Participants of the study almost have the same computed mean which means their responses do not differ from another. The standard error (SE) of 0.0817 , being relatively small, gives us an indication that our mean is relatively close to the true mean of the population.

\section{Difficulties of Teachers in Teaching Mother Tongue}

FIGURE 1

DIFFICULTIES IN TEACHING MOTHER TONGUE

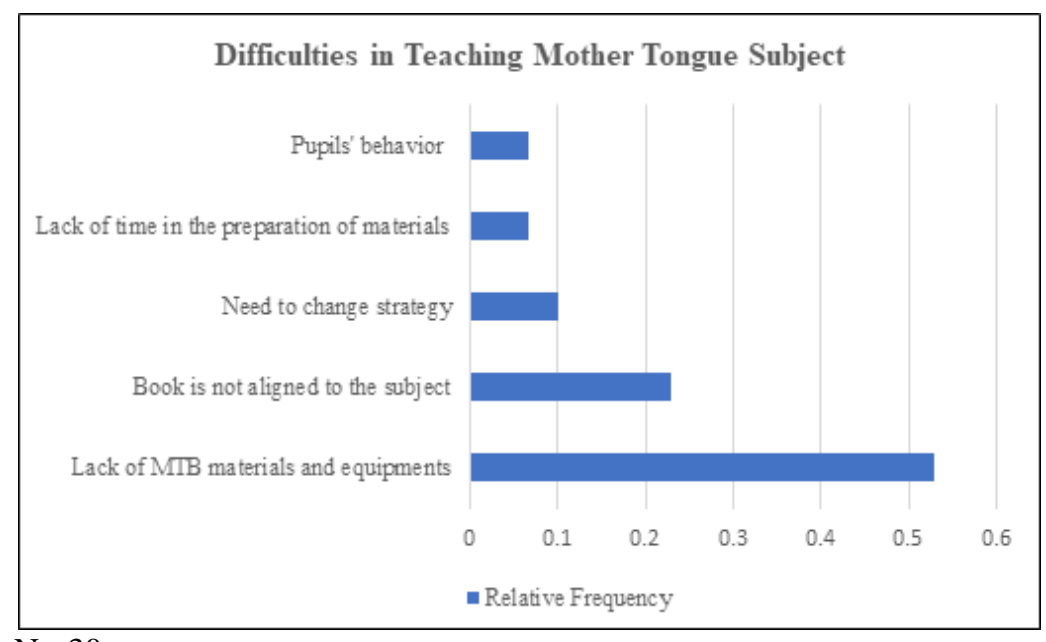

$\mathrm{N}=30$

Based on figure 1, lack of mother tongue based visual, multimedia materials and equipment are considered top problems of the teachers instead of strategy itself. Sixteen $(0.53 \mathrm{fN})$ participants 
unanimously perceive that in any teaching strategy instructional material is important. No strategy can be used without the right materials. It is not surprising that their main problem is the lack of materials. Some reiterated that if there are existing materials, some of them are not useful, damaged and obsolete. Because of scarcity and unavailability of IM's, teachers are forced to produce their own materials that allegedly consume their time and resources.

The Mother Tongue-Based Multilingual Education Program under the K to 12 Curriculum is now on its ninth year of implementation in the Philippines. But it seems that the most useful and common printbased instructional materials (IM's) are still hard to find or unavailable for the subject. In the study of Belisario (2014) on problems encountered by teachers in implementing Mother Tongue Based Instruction in Multilingual Classrooms, they found out that absence of books written in mother tongue, lack of vocabulary, and lack of teacher-training were very common. In the investigation made by Mangila (2019) as he analyzed the experiences of teachers in implementing the MTB-MLE Program in the selected elementary schools of Dumingag, Zamboanga del Sur; he found out that teachers often encounter various problems during the implementation of the MTB-MLE Program.

These problems include the absence of the instructional materials written in mother tongue, lack of teacher-trainings, lack of vocabulary, and language mismatch. The same problem faced by teachers who teach Mother Tongue here in Bulacan; but teachers do everything in their power to make materials available to their classes even if doing so is time consuming. It was also revealed in figure 1 that seven $(0.23 \mathrm{fN})$ teachers admit that the textbook that was given to them is inappropriate and lacks content.

\section{"The making of the book seemed hasty and the people responsible did not see what should be put in the book or even what the child needed to learn," teacher 4 added.}

When adults share picture books with young children, they build their lifelong literacy and enjoyment of reading (Jalongo, 2021). The content of the book should be short, apparent; equipped with logical fiction and include positive values (Hsiao \& Chang, 2015) as cited by Şerife Cengiz \& Erol Duran (2017) on their article. Hence, the right book with the right content with proper pictures will give children enough knowledge with whom teacher participants are requesting the concern office to produce. During the interview, the available materials are the teacher-made visual tools such as pictures, videos, charts and clip arts. Accordingly, these serve as remediation tools on how they will present and discuss their lessons effectively. This notion was supported by Perfecto (2018) when she mentioned in her paper that all her teacher participants used the visual aids like pictures/ illustrations or videos to generate students' interest in the learning of the English language. In relation to this, both previous and current participants are affirming the importance of visual materials in teaching language subjects in the primary level.

The figure also shows that two $(0.067 \mathrm{fN})$ of the teacher participants; though very small in numbers, also had problems with the students' behavior and they also lack the luxury of time in the development of teaching materials. They mentioned that no matter what strategy they use there are few students who do not listen and participate in the discussion or in any activity; instead, they do things irrelevant to the subject matter. Sun and Shek (2012) reported various classroom problem behaviors of students that are comparable to the students' behavior as stated by the teacher participants in the current study. Sun and Shek pointed out that "having disruptive conversation" and "talking out of turn," were the most common and the most disruptive to teaching and learning while "Inattentiveness/daydreaming/idleness" was the next common and disruptive problem behavior that affected. These problem behaviors are inappropriate in the classroom settings, as well as upsetting the classroom teaching and learning, which mainly require intervention from teachers. On the other hand, two teacher participants admitted that they do not have ample time to produce instructional materials. They were stressed with all the paperwork and heavy workload. This impression and experiences might result in leaving the profession if not given attention by the institution. There were teachers leaving the teaching force due to the workload, stress, general exhaustion, improve work life balance, not feeling valued, lack of support from the management, government initiatives and target driven culture. Among the enumerated reasons, workload has the most frequent responses of $83 \%$ to be followed 
by $76 \%$ of the improve work life balance. This brings disappointment on teaching, driving those who might have a significant contribution to make away from the profession (Perryman \& Calvert, 2019).

\section{Proposed Intervention Plan to Intensify the Competency of Teachers in Teaching Mother Tongue Subject}

Based on the interview conducted by the researcher, themes were transcribed from the responses of teachers. They have mentioned intervention programs in the form of seminars, lecture forums or workshops. They consider creation of the colorful instructional materials, module or textbook writing and teaching styles as the best topics for the program. These topics are good help to carry out teachers' strategies and will support student learning and increase students' success. In this program, different kinds of instructional materials are suggested to be presented. Sample verbalization are as follows with reference to the kind of intervention teachers would like to have:

Kind of intervention program teachers would like to have

T3,T11 "Seminar or lecture forum will help us"

T5 "I believe 2 days seminar is good for us, the second day could be workshop"

Topic for the training/workshop

T1-T2 "Create instructional materials that are colorful to arouse pupils' interest in the lesson."

T8 "If possible, module or textbook writing will help us coming out with our own material"

T12 "Techniques of teaching style so that we could have variation in teaching the subject, the seminar will refresh our stock knowledge which we have forgotten because of too many workloads"

$* T 3=$ teacher participant three

Rahayu (2011) proposed instructional materials entitled "Video Dora the Explorer " that enhanced students' vocabulary. He found out that this material is effective in teaching vocabulary. Students are learning while enjoying themselves. The teacher- respondent of this study would like to adopt the same but in a different format or design. They perceived that this could be an effective tool in improving students' vocabulary. Another instructional material that is unique in itself is metacards. Metacards are easy to use and proven to be highly effective engagement tools. This will place the pupils to be the center of the interaction; develop new skills, confidence and increase positivity (MetaCards \& Positive Coaching, n.d.). Metacards are useful especially for the slow learners. This is a good way to make pupils read by himself or through the help of his group mates.

Another verbalization of teacher participants goes like:

"Teachers may prepare and use electronic or digital IM's to improve the quality of learning that students can receive. Aside from learning how to read and write, concepts and theories; students also become technologically literate. Teachers may use power point presentations, animation, pictures and video clips. Of course, teachers should consider rules and standards in making slide presentations."

ICT generated instructional materials became a platform for more interactive and innovative materials. This will help bridge the gap between teacher and students, design a better educational environment and motivate students (Deb, 2016). A good classroom environment always has some elements of creativity which makes the lessons more interesting and interactive. The right mix of creativity along with curriculum helps students to be innovative and also encourages them to learn new things. Students can grow up as good 
communicators in addition to improving their emotional and social skills. Creativity has roles and benefits in today's classroom; it gives an opportunity for students to learn with fun. The teaching activities such as storytelling and skits help them to learn without the pressure of learning. Fun team building activities can be organized so as to promote creative thinking in groups and help them to learn about accepting others' ideas. Creativity can stimulate imaginative thinking capability in students. Activities such as board games and puppet shows will keep the students interested in the learning sessions and the flow of images in their mind gives them the pleasure of creativity. Children have a very short attention span, so teachers need to keep in mind that pupils need a variety of activities. Teachers should simplify the activities; the task must be motivating and stimulating so that young learners can feel satisfied with what they have done. They are curious learners, imaginative and playful. They develop as individuals very quickly and enjoy routines and repetitions. Young learners do not like to work alone, but to be accompanied by others especially when playing (Slattery, M., \& Willis, J., 2001). Through play, they learn to get along with others, sort out conflicts, practice language skill; they also develop small and large motor skills. Play encourages independence, self- esteem, creativity and gets their energy out (Maria Norissa Daño, 2017). Furthermore, it is the role of a teacher to bring in the right mix of creativity in classrooms and bring out the best in the students. These could be one of the reasons for the teacher-participants to initiate an intervention plan. Below is the program the researcher would like to propose based on the needs of the teacher. This can be done before the return of limited face to face class in the country.

\section{Proposed Program:}

Seminar Theme: Interactive IMs and Teaching Strategies: Connecting with Mother Tongue Learners

\section{Rationale}

It is the goal of the Department of Education that every teacher will become not only efficient but also effective. Training and seminars are being conducted to improve teaching capability and bring learning to the heart of every pupil. Teachers' attendance to these seminars will create an effective learning environment, improve teaching-learning situations, keep updated on instructional devices and inspire them to become better teachers in the modern world.

II. Objectives

1. To make teachers aware of the different materials / aids and techniques in teaching Mother Tongue subjects.

2. To recognize the power of teaching aids in making every student an active participant in the classroom.

3. To provide teachers reinforcement for better teaching and learning Mother Tongue as a subject.

4. To make the learning permanent among the students with the use of teaching materials.

5. To produce original metacards, board games, powerpoint presentations, digital games and other visual materials after the sessions.

III. Seminar Matrix 


\section{TABLE 6}

\section{PROPOSED SEMINAR MATRIX}

\begin{tabular}{|c|c|}
\hline TOPIC \& TITLE & DESCRIPTION \\
\hline $\begin{array}{l}\text { Interactive Teaching } \\
\text { materials and teaching } \\
\text { techniques }\end{array}$ & $\begin{array}{l}\text { The interactive teaching materials can improve the reading, writing and } \\
\text { speaking skills of the students. It can reinforce ideas, facts or skills that } \\
\text { have already been learnt by the students. These interactive teaching aids } \\
\text { help to remove the anxiety, fear, boredom or any other complex feeling } \\
\text { which the students may develop while learning their subjects of study. } \\
\text { Teaching techniques will create a positive school climate and responsive } \\
\text { classroom, thus enhancing students' learning experiences. }\end{array}$ \\
\hline $\begin{array}{l}\text { Session } 1 \\
\text { MetaCards and Tok-a- } \\
\text { Talk Board Game }\end{array}$ & $\begin{array}{l}\text { MetaCards is a set of pictorial cards designed to help students assess their } \\
\text { difficulty in putting ideas; this will enable them to better express } \\
\text { themselves. } \\
\text { "Tok-A-Talk" board game inspired by Snakes and Ladders. The design of } \\
\text { the board will be chosen in lieu with the Filipino tradition. The features of } \\
\text { the game will be modified; for every door pupils will encounter questions } \\
\text { that will enrich their ability for oral language. Tok came from the sound of } \\
\text { a knock on a door and Talk, which came from the sole purpose of the board } \\
\text { game itself. Questions will focus on the vocabulary development and its } \\
\text { proper usage and fun fact riddles anchored in the curriculum of the Mother } \\
\text { Tongue subject. This is a chance for the students to bond with the other } \\
\text { students while going through the lesson and probably will enrich students' } \\
\text { fluency in reading and sentence construction. }\end{array}$ \\
\hline $\begin{array}{l}\text { Session } 2 \\
\text { Dora, the Words, } \\
\text { Explorer Game }\end{array}$ & $\begin{array}{l}\text { "Dora, the Words" Explorer " is a visual material that will catch students' } \\
\text { attention while improving reading comprehension skills. This will relieve } \\
\text { anxiety or boredom during class hours because of different ways of } \\
\text { presenting information. This intervention contains five characters: "Dora" } \\
\text { will be used to teach parts of a short story, "Boots" to represent synonyms } \\
\text { and contradiction of words, "Swiper" to present diphthongs, "I am the Map" } \\
\text { to present the waste separation and "Benny" to present the parts of a letter. } \\
\text { In selecting each lesson, MTB-MLE book and curriculum guide are the best } \\
\text { references. }\end{array}$ \\
\hline $\begin{array}{l}\text { Session } 3 \\
\text { Power point slides and } \\
\text { games }\end{array}$ & $\begin{array}{l}\text { PowerPoint slides and games can be used by interpolating sounds and } \\
\text { animations in the text lessons making the lessons very interesting to the } \\
\text { students. This can be used by having an LED TV in the classroom. }\end{array}$ \\
\hline
\end{tabular}

IV. Methodology and Evaluation

The proposed two-day seminar -workshop will be held during the semestral break of the Basic Education Mother Tongue teachers and students. It will be recorded so that it can still be watched by those who were absent during the actual seminar. The seminar workshop will be evaluated right after the said event. There will be a follow-up assessment to those teachers who were able to make and use the suggested materials in their teachings of Mother Tongue. 


\section{CONCLUSION}

Basic education schools in the Philippines are compliant to the mandate of Mother Tongue Based Multilingual Education Program (MTB-MLE) as special program under the K to 12 Curriculum of the Department of Education. Teachers handling Mother Tongue subject use a variety of strategies that they think are effective. Teacher participants considered either student centered or teacher centered strategies the most useful, motivating and stimulating to learners specifically if these will bring enthusiasm and teamwork. Along with the result, this study found out that teachers' difficulty is not directly connected to strategy itself; rather, to the lack of Mother Tongue-based visual and multimedia materials and equipment which hold back the enhancement of different macro skills and language competency of the learners. Nevertheless, teachers find ways to produce visual and other related materials and equipment in spite of heavy workload and even it cost them a lot.

\section{RECOMMENDATIONS}

Considering all the findings and conclusion, the following recommendations are drawn:

1. Mother Tongue Subject teachers should develop appropriate and local instructional material, specifically a textbook in MTB for the use of students; then evaluate the material annually.

2. Filipino specialists, MTB teachers and other school and community personnel may work hand in hand in the production of intervention materials as suggested by teacher participants and use them as part of their continuous improvement plan.

3. Demonstration, Differentiated and Game- based strategies can also be tested by other MTB teachers especially if they are not used to these; other strategies can also be utilized.

4. The proposed seminar workshop will be executed before the return of the face to face classes so that MTB teachers are ready to use the interactive teaching materials and teaching strategies.

5. Aside from the proposed program, the school may develop a long term intervention program that will enhance students' ability to understand, write and speak Mother Tongue fluently.

6. A similar study is recommended in a different locale and at a bigger scope so that a more accurate picture of Mother Tongue Subject teachers' challenges will be drawn.

\section{REFERENCES}

Bhattacharjee, B., \& Deb, K. (2016). Role of ICT in 21st Century's Teacher Education. International Journal of Education and Information Studies, 6(1), 1-6. Retrieved from https://www.ripublication.com/ijeis16/ijeisv6n1_01.pdf

Boudersa, N. (2016, October 17). The Importance of Teachers' Training Programs and Professional Development in the Algerian Educational. ResearchGate; unknown. Retrieved from https://www.researchgate.net/publication/309430087_The_Importance_of_Teachers\%27_Trainin g_Programs_and_Professional_Development_in_the_Algerian_Educational_Context_Toward_In formed_and_Effective_Teaching_Practices

Burguillo, J.C. (2010, September). Using game theory and Competition-based Learning to stimulate student motivation and performance. ResearchGate; Elsevier. Retrieved from https://www.researchgate.net/publication/222785687_Using_game_theory_and_Competitionbased_Learning_to_stimulate_student_motivation_and_performance

Castillo Llaneta, C.A. (2018, February 6). Teaching in mother tongues. University of the Philippines System Website. Retrieved from https://up.edu.ph/teaching-in-mother-tongues/

Cengiz, Ş., \& Duran, E. (2017, July 6). Analysis of Values on Preschool Period Children Story and Tale Books. ResearchGate. Retrieved September 6, 2021, from https://www.researchgate.net/publication/318253331_Analysis_of_Values_on_Preschool_Period _Children_Story_and_Tale_Books 
Daño, M.N. (2020). InnovativETEaching StratEgiEs. Academia.edu. Retrieved from https://www.academia.edu/31716163/InnovativE_TEaching_StratEgiEs

Department of Education. (2012). February 17, 2012, DO 16, s. 2012 - Guidelines on the Implementation of the Mother Tongue-Based-Multilingual Education (MTB-MLE)| Department of Education. Retrieved from https://www.deped.gov.ph/2012/02/17/do-16-s-2012-guidelines-on-theimplementation-of-the-mother-tongue-based-multilingual-education-mtb-mle/

Department of Education. (2016). K to 12 Curriculum Guide MOTHER TONGUE (Grade 1 to Grade 3) $K$ to 12 BASIC EDUCATION CURRICULUM K to 12 Mother Tongue Curriculum Guide MTBMLE CURRICULUM FRAMEWORK. Retrieved from https://www.deped.gov.ph/wpcontent/uploads/2019/01/Mother-Tongue-CG.pdf

Department of Education. (n.d.). DepEd underscores need for training and development programs for close to a million teachers, personnel Department of Education. Retrieved July 22, 2021, from https://www.deped.gov.ph/2019/08/17/deped-underscores-need-for-training-and-developmentprograms-for-close-to-a-million-teachers-personnel/

Dworkin, S.L. (2012). Sample Size Policy for Qualitative Studies Using In-Depth Interviews. Archives of Sexual Behavior, 4l(6), 1319-1320. https://doi.org/10.1007/s10508-012-0016-6

Felipe, R.B. (2013, March 29). The Importance of Seminars and Trainings in Improving Teachers Performance | Teachers' Essay. Teachers' Essay | It's All about Teachers Thought, Experiences and Observations of Daily School Life. Retrieved from http://www.teachersessay.com/theimportance-of-seminars-and-trainings-in-improving-teachers-performance/

Gitamarsita, S.R. (2011). The Effectiveness of Teaching Vocabulary by Using Video Dora the Explorer of the Fifth-Grade Students at SD N 2 Sucen Juuru Tengah in the Academic Year 2011/2012. Umpwr.ac.id. https://doi.org/http://repository.umpwr.ac.id:8080/handle/123456789/3436

Guven, I., Yurdatapan, M., \& Sahin, F. (2014). The Effect of Project-Based Educational Applications on the Scientific Literacy of 2nd Grade Elementary School Pupils*. International Journal of Education and Research, 2(1). Retrieved from https://ijern.com/journal/January-2014/34.pdf

Hugerat, M., Basheer, A., Kortam, N., \& Hofstein, A. (2016). The Effectiveness of Teachers' Use of Demonstrations for Enhancing Students' Understanding of and Attitudes to Learning the Oxidation-Reduction Concept. EURASIA Journal of Mathematics, Science and Technology Education, 13(3). https://doi.org/10.12973/eurasia.2017.00632a

IIEP-UNESCO Learning Portal. (2018). Effective and appropriate pedagogy. Retrieved from www.learningportal.iiep.unesco.org/en/issue-briefs/improve-learning/teachers-andpedagogy/effective-and-appropriate-pedagogy

Jalongo, M. (2021). Young Children and Picture Books (2nd Edition). In National Association for the Education of Young Children. Retrieved from https://eric.ed.gov/?id=ED489849

Kini, T., \& Podolsky, A. (2016). Does Teaching Experience Increase Teacher Effectiveness? A Review of the Research. Learning Policy Institute. Retrieved from https://learningpolicyinstitute.org/ product/does-teaching-experience-increase-teacher-effectiveness-review-research

Kirby, M. (2020). Mëranaw Mother Tongue Schools Findings Report. Retrieved from https://pdf.usaid.gov/pdf_docs/PA00WKGZ.pdf

Lartec, J.K., Belisario, A.M., Bendanillo, J.P., Binas-o, H.K., Bucang, N.O., \& Cammagay, J.L.W. (2014). Strategies and Problems Encountered by Teachers in Implementing Mother Tongue Based Instruction in a Multilingual Classroom. IAFOR Journal of Language Learning, 1(1). https://doi.org/10.22492/ijll.1.1.04

Mangila, B.B. (2019, April). Institutionalizing a Mother Tongue-Based Approach in Teaching Multicultural Classrooms: A Closer Look at Elementary Teacher's Experience. Research Gate. Retrieved from https://www.researchgate.net/publication/338293980_Institutionalizing_a_ Mother_Tongue-Based_Approach_in_Teaching_Multicultural_Classrooms_A_Closer_Look_at_ Elementary_Teachers'_Experiences 
Perfecto, M.R.G. (2018). English language teaching and bridging in mother tongue-based multilingual education. International Journal of Multilingualism. Retrieved from https://www.tandfonline.com/doi/full/10.1080/14790718.2020.1716771

Perryman, J., \& Calvert, G. (2019). What Motivates People to Teach, and Why Do They Leave? Accountability, Performativity and Teacher Retention. British Journal of Educational Studies, 68(1), 1-21. https://doi.org/10.1080/00071005.2019.1589417

Podolsky, A., Kini, T., \& Darling-Hammond, L. (2019, June 28). Does teaching experience increase teacher effectiveness? A review of US research. ResearchGate; Emerald (MCB UP ). Retrieved from https://www.researchgate.net/publication/334096687_Does_teaching_experience_increase_ teacher_effectiveness_A_review_of_US_research

Positive Steps. (n.d.). MetaCards \& Positive Coaching. Retrieved July 22, 2021, from https://www.positive-steps.org.uk/images/Positive-Coaching/Positive-Coaching-Brochure.pdf

Slattery, M., \& Willis, J. (2001). English for Primary Teachers. Oxford University Press. - References Scientific Research Publishing. (2019). Scirp.org. Retrieved from https://www.scirp.org/ (S(351jmbntvnsjt1aadkposzje))/reference/ReferencesPapers.aspx?ReferenceID=2635930

Standard Deviation. (2012). Nih.gov; U.S. National Library of Medicine. Retrieved from https://www.nlm.nih.gov/nichsr/stats_tutorial/section2/mod8_sd.html

Sun, R.C.F., \& Shek, D.T.L. (2012). Student Classroom Misbehavior: An Exploratory Study Based on Teachers' Perceptions. The Scientific World Journal, 2012, 1-8. https://doi.org/10.1100/2012/208907

Susman, D. (2021). Preoperational Stage of Cognitive Development in Young Children. Verywell Mind. Retrieved from https://www.verywellmind.com/preoperational-stage-of-cognitive-development2795461

Teach.com. (2020). Teaching Methods. Retrieved September 6, 2021, from https://teach.com/what/teachers-know/teaching-methods/

Thomson, N. (2012). Language Teaching Strategies and Techniques Used to Support Students Learning in a Language other than Their Mother Tongue. Retrieved from https://www.ibo.org/contentassets/4ccc99665bc04f3686957ee197c13855/thompson_execsum_829-12.pdf

Tomlinson. C.A. (2014). Deciding to Teach Them All. ASCD. Retrieved from https://www.ascd.org/el/articles/deciding-to-teach-them-all

Tzippy, S., \& Hadassah, L. (2019). Lax Differentiated Instruction Through the Lens of Multiple Intelligences. Kohelet Prize. Retrieved from https://koheletprize.org/database/ differentiatedinstruction-through-the-lens-of-multiple-intelligences/

UNESCO. (2019, September 26). Classroom practices | Education | IIEP Policy Toolbox. IIEP Policy Toolbox | Education Policy Toolbox. Retrieved from https://policytoolbox.iiep.unesco.org/policyoption/clasroom-practices/

Vusić, D., \& Geček, R. (2018). Instructional design in game based learning and applications used in educational systems. Tehnički Glasnik, 12(1), 11-17. Retrieved from https://www.researchgate.net/publication/328757635_Instructional_design_in_game_based_learn ing_and_applications_used_in_educational_systems

Vusic, D., \& Gecek, R. (2018, March 27). Instructional design in game based learning and applications used in educational systems. ResearchGate; University North. Retrieved from https://www.researchgate.net/publication/328757635_Instructional_design_in_game_based_learn ing_and_applications_used_in_educational_systems 